\title{
Geochemistry and provenance of the Carboniferous Baixo Alentejo Flysch Group, South Portuguese Zone
}

\author{
R.C.G.S. Jorge ${ }^{\text {a, } *}$, P. Fernandes ${ }^{\text {b }}$, B. Rodrigues ${ }^{\text {b }}$, Z. Pereira ${ }^{c}$, J.T. Oliveira ${ }^{\text {d }}$ \\ a CREMINER (LA-ISR), Universidade de Lisboa, Faculdade de Ciências, Departamento de Geologia, Edificio C6, Piso 4, Campo Grande, $1749-016$ Lisboa, Portugal

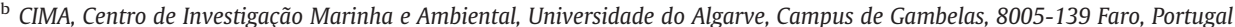 \\ c LNEG-LGM, Unidade de Geologia e Cartografia Geológica, Rua da Amieira, 4465-965S. Mamede Infesta, Portugal \\ d LNEG-LGM, Unidade de Recursos Naturais e Geofísica, Apartado 7586, 2611-901 Alfragide, Portugal
}

\section{A R T I C L E I N F O}

\section{Article history:}

Received 2 February 2012

Received in revised form 21 November 2012

Accepted 7 December 2012

Available online $\mathrm{xxxx}$

Editor: G.J. Weltje

\section{Keywords:}

Baixo Alentejo Flysch Group

South Portuguese Zone

Carboniferous

Whole-rock geochemistry

Provenance analysis

\begin{abstract}
A B S T R A C T
This work is focused on the turbiditic sediments from the Carboniferous Baixo Alentejo Flysch Group (BAFG) in the South Portuguese Zone, an external zone of the Iberian Variscides. The aim of this work is to constrain the provenance and tectonic setting of these sediments in a context of a complex evolution of SW Iberian Variscides. For this purpose, we performed a systematic study of petrographical and geochemical signatures of greywackes and shales from the three BAFG formations: Mértola, Mira and Brejeira. Major and trace element composition and ratios suggest heterogeneous source area composition for BAFG shales and greywackes. For the oldest Mértola Formation greywackes, source area is dominated by granitoid rocks with minor mafic input. The latter becomes residual in the Mira Formation. The youngest Brejeira Formation greywackes show clear felsic affiliation associated with an increase in recycled components. The shales of all three BAFG formations denote a granodioritic affiliation. Chemical Index of Alteration (CIA) and Plagioclase Index of Alteration (PIA) values suggest moderate weathering in the source areas of Mértola and Mira formations. These indices, together with A-CN-K relations, point out to steady-state weathering conditions in the source areas of both formations. In contrast, both CIA and PIA values for the Brejeira Formation indicate variable conditions of palaeoweathering, from moderate to intense, as a consequence of non-steady-state conditions probably triggered by tectonic instability in the provenance area. Compared to the greywackes, the shales of all three BAFG formations exhibit higher CIA and PIA values, as well as low $\mathrm{K}_{2} \mathrm{O} / \mathrm{Al}_{2} \mathrm{O}_{3}(\sim 0.2)$ and index of compositional variability $(<1)$, reflecting the cumulative effect of multiple cycles of sedimentary recycling and prolonged chemical weathering history. Major and trace element distribution and upper continental crust-normalized multi-element plots suggest that the sediments of BAFG were derived mainly from a continental arc/active margin with minor contribution from old continental crust. Together, our geochemical data are compatible with BAFG sediments derived mainly from SW border of the Ossa Morena Zone (Gondwanan affinity), with possible contribution from an external (Avalonian) source.
\end{abstract}

(c) 2012 Elsevier B.V. All rights reserved.

\section{Introduction}

Provenance analysis of siliciclastic sediments is a powerful tool in elucidating the evolution of ancient sedimentary basins. Diverse techniques based on petrographic and geochemical criteria have been successfully used for this purpose (e.g., Dickinson and Suczek, 1979; Ingersoll et al., 1984; Taylor and McLennan, 1985; Wronkiewicz and Condie, 1987; McLennan, 1989; McLennan et al., 1990, 1993; Zuffa, 1991; McLennan and Hemming, 1992). Geochemistry of major and trace elements of siliciclastic rocks provides valuable information regarding the composition of the sediment source areas, palaeoweathering conditions,

\footnotetext{
* Corresponding author.

E-mail addresses: rjorge@fc.ul.pt (R.C.G.S. Jorge), pfernandes@ualg.pt (P. Fernandes), bmgrodrigues@sapo.pt (B. Rodrigues), zelia.pereira@lneg.pt (Z. Pereira), tomas.oliveira@lneg.pt (J.T. Oliveira).
}

hydraulic selection, recycling and, in some cases, the tectonic setting of the sedimentary basins (e.g., Nesbitt and Young, 1982; Bhatia and Crook, 1986; Fedo et al., 1995; Bauluz et al., 2000; Cullers and Podkovyrov, 2002; McLennan et al., 2003; Armstrong-Altrin et al., 2004; Slack et al., 2004; Veizer and Mackenzie, 2005; Etemad-Saeed et al., 2011). A main premise relies on the assumption that certain trace elements (e.g., Th, Sc, Rare Earth Elements (REE)) tend to stay in a particulate phase during weathering, erosion and transport, and thus are transferred to a sedimentary record proportionally to their abundances in the source area (McLennan et al., 1990).

Geodynamic and palaeogeographic reconstructions place the South Portuguese Zone (SPZ, Fig. 1) as an external zone of the Iberian Variscides and thus a possible western equivalent of the northern Variscan belt (i.e. southwest England and Ireland, and Rhenohercynian Zone of northwest Germany; Ribeiro et al., 1990, 2007; Oliveira and Quesada, 1998; Franke, 2000; von Raumer et al., 2003; Nance et al., 